\title{
PENGARUH JUMLAH MATA PANCING LONGLINE TERHADAP LAJU PANCING DAN JUMLAH HASIL TANGKAPAN IKAN TUNA SIRIP KUNING (Thunnus albacares) DI PPS NIZAM ZACHMAN JAKARTA
}

\author{
Longline Hook Number Effect on Catch Rate and Catch of Yellowfin Tuna (Thunnus albacares) at \\ PPS Nizam Zachman, Jakarta
}

Oleh:

Rahman Arif Firmansyah ${ }^{1}$, Indah Riyantini ${ }^{1}$, Ibnu Bangkit Bioshina Suryadi ${ }^{1}$ dan Izza Mahdiana Apriliani ${ }^{1}$

${ }^{1}$ Fakultas Perikanan dan Ilmu Kelautan, Universitas Padjadjaran

Korespondensi: rahmanariffirmansyah@gmail.com

\begin{abstract}
ABSTRAK
Tujuan penelitian untuk menentukan penggunaan jumlah mata pancing yang efektif terhadap laju pancing dan jumlah hasil tangkapan ikan tuna sirip kuning (Thunnus albacares), dengan menggunakan alat tangkap longline yang didaratkan di PPS Nizam Zachman. Penelitian telah dilaksanakan di Bagian Operasional Kantor Syahbandar PPS (PPS) Nizam Zachman, Muara Baru DKI Jakarta dengan mengumpulkan data hasil tangkapan ikan tuna yang didaratkan dari kapal longline. Penelitian dilaksanakan pada bulan Maret-April 2017. Metode yang digunakan dalam penelitian adalah metode survey dari data sekunder yang diperoleh dari laporan armada kapal penangkapan ikan yang melakukan operasi penangkapan ikan tuna sirip kuning. Parameter yang diamati adalah jumlah mata pancing menggunakan 800 mata pancing, 1200 mata pancing dan 1592 mata pancing. Hasil tangkapan ikan tuna sirip kuning pada tahun 2016 terbanyak jumlahnya adalah dengan penggunaan alat tangkap longline dengan 1592 mata pancing dan hasil tangkapan terendah dengan penggunaan 1200 mata pancing. Penggunaan 1592 mata pancing mendapatkan hasil tangkapan tertinggi dikarenakan beberapa faktor, diantaranya sifat renang migrasi ikan tuna sirip kuning secara bergerombol sehingga penggunaan jumlah mata pancing yang lebih banyak memperbesar peluang tertangkapnya ikan tuna sirip kuning dan semakin sedikit jumlah mata pancing yang digunakan akan memperkecil peluang tertangkapnya ikan tuna sirip kuning dan membuat alat tangkap tersebut kurang efisien.
\end{abstract}

Kata kunci: hasil tangkapan, ikan tuna sirip kuning, jumlah mata pancing

\section{ABSTRACT}

The purpose of this research is to deternine the effective usage number of longline fishing hook towards fishing rate and number of catches of yellow fin tuna landed in Nizam Zachman Fishing Port. The research was conducted in March-April 2017 at Syahbandar Operational Port of Ocean Fishery Nizam Zachman, Muara Baru DKI Jakarta by collecting yellowfin tuna catch data landed from a longline fishing ships. The method used in this research is survey method from secondary data obtained from fishing fleet vessel report which performed yellowfin tuna fishing operation. The parmeters observed were the amount of fishing hook using 800 hooks, 1200 hooks and 1592 hooks. The highest yellowfin tuna catch in 2016 was using 1592 hooks and the lowest yellowfin tuna catch was using 1200 hooks. The use of 1592 hooks become the highest number of catch due to numbers of factors such as the migration pattern of yellowfin tuna and schooling behaviour which leads to the higher amount of fishing hook used the higher yellow fin tuna catched and increase the effectivity and vice versa.

Key words: number of catches, numbers of fishing hook, yellowfin tuna 


\section{PENDAHULUAN}

Tuna longline merupakan salah satu alat tangkap kelompok pancing yang digunakan dalam menangkap ikan pelagis. Berdasarkan Farid et al. (1989) konstruksi alat tangkap longline mampu menjangkau swimming layer tuna. Produksi tuna di dunia sebanyak $40 \%$ ditangkap dengan alat tangkap longline, selebihnya sebanyak 60\% dihasilkan oleh purse seine, trawlserta alat tangkap lainnya (Simorangkir 1982). Alat tangkap tuna longline juga merupakan alat tangkap yang selektif terhadap hasil tangkapannya dan cara pengoperasiannya bersifat pasif sehingga tidak merusak sumber daya hayati perairan (Nugraha et al. 2010).

Konstruksi tuna longline dalam satu basket umumnya menggunakan 6 mata pancing dan jarak pemasangan antar tali cabang (branch line) sebesar 50 meter dengan panjang tali utama sebesar 350 meter. Nelayan Indonesia pada umumnya membawa dan mengoperasikan alat tangkap rawai tuna sebanyak 100 basket atau 100 unit. Rawai tuna atau tuna longline merupakan alat penangkap tuna yang efektif dikarenakan pengoperasian jenis pancing yang dibentuk secara rawai (rangkai) dan dioperasikan sekaligus. Satu tuna longliner biasanya mengoperasikan 1.000-2.000 mata pancing untuk sekali turun (Subani 1989).

Rawai tuna dioperasikan di laut lepas atau bahkan mencapai perairan samudera. Alat tangkap ini bersifat pasif yaitu menanti umpan dimakan oleh ikan target. Berdasarkan Musyaffa (2016) proses setting alat tangkap longline dilakukan dengan kondisi mesin kapal dimatikan mesinnya, sehingga pancing yang diturunkan akan hanyut oleh arus atau dapat disebut dengan drifting. Drifting berlangsung selama kurang lebih empat jam. Selanjutnya proses hauling alat tangkap yaitu pancing diangkat kembali ke atas kapal dan mengambil hasil tangkapan.

Ikan tuna (Thunnus sp.) merupakan spesies yang ditargetkan secara komersial dan merupakan salah satu komponen yang paling berharga dalam perikanan tangkap longline di Samudera Hindia. Samudera Hindia mendukung perikanan tuna terbesar kedua di dunia setelah Samudera Pasifik, dengan memberikan kontribusi 24\% dari total produksi global (Syamsuddin et al. 2013).

Tuna merupakan salah satu jenis ikan pelagis besar yang penyebarannya hampir di seluruh perairan Indonesia. Jenis ikan tuna yang terpenting di Indonesia diantaranya yaitu madidihang, tuna mata besar, albacore dan tatihu/tuna sirip biru selatan. Ikan madidihang merupakan jenis ikan tuna yang paling dominan di daerah tropis termasuk Indonesia.

Pelabuhan Perikanan Samudera (PPS) Nizam Zachman merupakan salah satu Unit Pelaksana Teknis (UPT) dari Kementrian Kelautan dan Perikanan yang berada di bawah dan bertanggung jawab kepada Direktorat Jenderal Perikanan Tangkap. Berdasarkan data yang tertulis sesuai dengan Surat Ijin Penangkapan Ikan (SIPI) ada sekitar 1478 kapal yang terdaftar di PPS Nizam Zachman, Muara Baru, Jakarta Utara. Hasil tangkapan di PPS Nizam Zachman Jakarta yaitu ikan tuna, ikan cakalang, ikan tongkol, ikan madidihang, dan ikan tenggiri. Total produksi hasil tangkapan ikan di pelabuhan Nizam Zachman hingga mencapai 350 ton per hari dengan 70\% hasil tangkapannya adalah ikan tuna (Mahyuddin, 2014).

Kapal longline dalam operasi penangkapan ikan tuna yang dilakukan di PPS Nizam Zachman menggunakan jumlah mata pancing dan tonase kapal yang berbeda setiap kapal, kapal yang beroperasi dengan alat tangkap longline berukuran 118 GT memiliki total 800 mata pancing dan kapal yang beroperasi dengan alat tangkap longline berukuran 152 GT memiliki 1500 mata pancing (Pusat Informasi PPS Nizam Zachman 2016). 
Menurut Triharyuni (2013) banyaknya mata pancing yang digunakan berpengaruh nyata atau dapat mempengaruhi jumlah hasil tangkapan ikan tuna sirip kuning. Tujuan dari penelitian ini adalah untuk mengetahui penggunaan jumlah mata pancing paling efektif untuk menangkap ikan tuna sirip kuning.

\section{METODE PENELITIAN}

Penelitian ini dilaksanakan pada bulan Februari-Maret 2017 di PPS Nizam Zachman Jakarta. Pemilihan tempat penelitian berdasarkan banyaknya ikan tuna yang didaratkan dan data pelayaran yang dimiliki oleh pelabuhan tersebut. Metode yang digunakan dalam pengumpulan data pada penelitian ini adalah metode survei dengan mengamati dan mengolah data yang tersedia dalam logbook yang ada di PPS Nizam Zachman Jakarta dalam kurun satu tahun terakhir. Data penunjang yang digunakan diperoleh dari hasil tangkapan dari kapal longline sebanyak tiga kapal longline. Prosedur yang diterapkan dalam penelitian ini adalah:

a) Persiapan penelitian

b) Pengambilan data logbook dan mencatat hasil tangkapan ikan tuna sirip kuning pada kapal tuna longline selama 12 bulan dari tiga kapal yang berbeda dengan pengoperasian jumlah mata pancing 800, 1200 dan 1500 mata pancing.

c) Melakukan perhitungan hasil tangkapan ikan tuna sirip kuning menggunakan software yang mendukung penelitian.

d) Melakukan analisis nilai hasil tangkapan ikan tuna sirip kuning.

Data utama yang digunakan dalam penelitian ini bersumber dari data pendaratan ikan yang tercatat di logbook yang tersedia di Pelabuhan Perikanan Nizam Zachman Jakarta selama satu tahun terakhir. Perhitungan laju pancing didapatkan berdasarkan data hasil tangkapan dan upaya penangkapan nelayan yang tercatat pada logbook yang ada di Pelabuhan Perikanan Nizam Zachman Jakarta, perhitungan laju pancing tersebut menggunakan rumus laju pancing atau hook rate. Persamaan yang digunakan untuk menghitung HR, menurut Widodo et al. (1998) adalah:

Keterangan:

$$
\mathrm{HR}=\frac{\mathrm{I}}{\mathrm{H}} \mathrm{X} 100
$$

$\mathrm{HR}=$ Hook rate

I = Jumlah ikan yang tertangkap (ekor per trip)

$\mathrm{H} \quad$ = Jumlah mata pancing yang digunakan selama operasi (unit mata pancing per trip)

Hubungan perbedaan jumlah mata pancing dengan hasil tangkapan dapat menggunakan rumus analisis korelasi dengan rumus sebagai berikut:

$$
r=\frac{\sum(x-\bar{x})(y-\bar{y})}{\sqrt{\sum(x-\bar{x})^{2} \sum(y-\bar{y})^{2}}}
$$

Keterangan:

$\mathrm{r} \quad=$ Pearson $\mathrm{r}$ koefisien korelasi

$\mathrm{x} \quad$ = variabel bebas berupa jumlah mata pancing

$\overline{\mathrm{x}} \quad$ = rata-rata variabel $\mathrm{x}$ (jumlah mata pancing)

$\mathrm{y} \quad$ = variabel tidak bebas berupa hasil tankap ikan tuna sirip kuning

$\overline{\mathrm{y}} \quad$ = rata-rata varibel y (hasil tangkap)

Analisis regresi dalam penelitian menurut Sugiyono (2013), menggunakan analisis regresi sederhana dengan persamaan koefisien regresi, sebagai berikut:

$$
Y=a+b X
$$


Keterangan:

a $\quad=$ Intercept

$\mathrm{b} \quad=$ Koefisien regresi

$X \quad=$ Variabel bebas (jumlah mata pancing)

\section{HASIL DAN PEMBAHASAN}

\section{Jumlah Hasil Tangkapan}

Operasi penangkapan ikan tuna sirip kuning menggunakan tiga kapal yang menggunakan alat tangkap longline dan memiliki hasil tangkapan yang berfluktuasi pada setiap bulannya. Hasil tangkapan ikan tuna sirip kuning (Gambar 1) tertinggi pada bulan Maret dengan jumlah hasil tangkapannya sebanyak 66 ekor ikan tuna sirip kuning dari 3 kapal yang beroperasi. Hasil tangkapan ikan tuna sirip kuning terendah pada bulan Oktober dengan jumlah hasil tangkapan 54 ekor ikan tuna sirip kuning dari tiga kapal yang beroperasi. Hasil tangkapan yang paling besar pada bulan Maret diindikasikan bahwa migrasi ikan tuna sirip kuning terjadi pada bulan tersebut, dan pada bulan lainya hasilnya berfluktuasi, ikan tuna hanya berenang untuk mencari makan (Nakamura 1969). Hasil tangkapan terendah pada bulan Oktober diindikasikan bahwa pada bulan tersebut hasil tangkap yang didapatkan oleh kapal tuna longline dengan jumlah mata pancing 800 mata pancing didominasi oleh ikan lainnya seperti ikan tuna mata besar maka dari itu hasil tangkap ikan tuna sirip kuning pada bulan tersebut memiliki hasil tangkapan paling rendah.

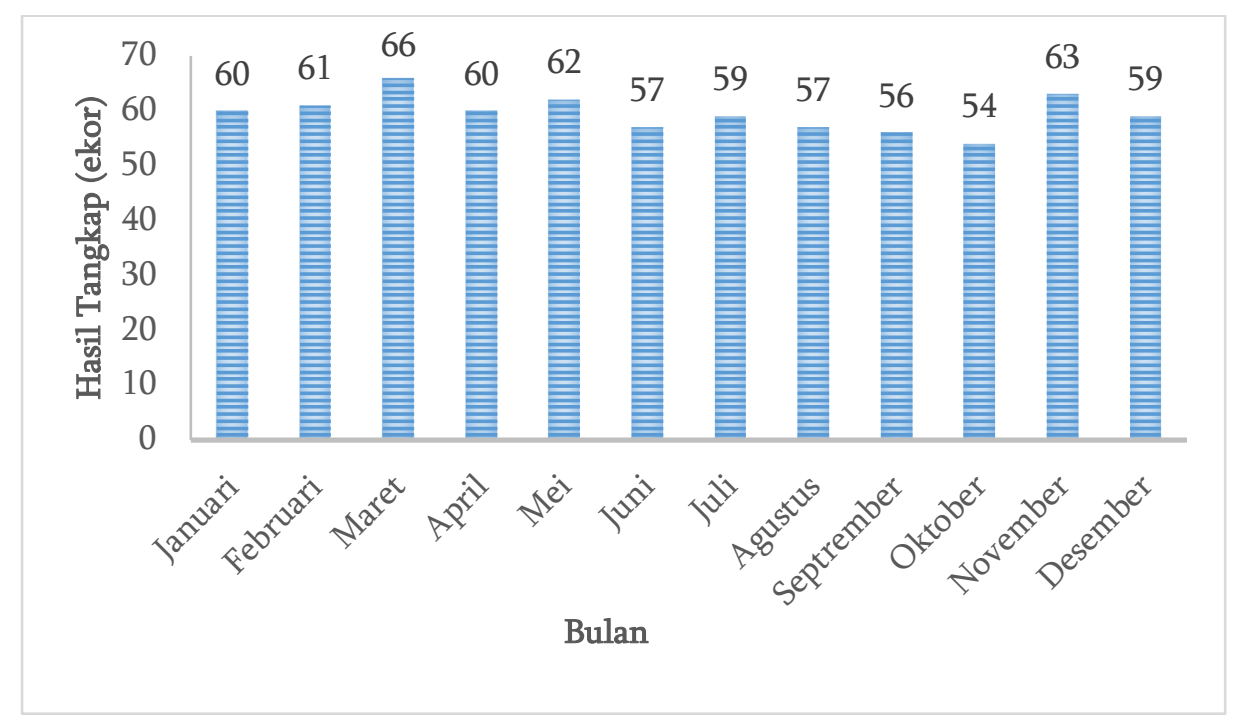

Gambar 1 Jumlah hasil tangkapan total ikan tuna sirip kuning tahun 2016

Jumlah hasil tangkapan total ikan tuna sirip kuning pada tahun 2016 yang ditunjukkan pada Gambar 2 memperoleh hasil bervariasi dan berfluktuasi. Perbedaan jumlah hasil tangkapan ikan tuna sirip kuning dengan penggunaan 800 mata pancing, 1200 mata pancing dan 1592 mata pancing banyak dipengaruhi oleh beberapa faktor dan hasil tangkapan berbeda. 


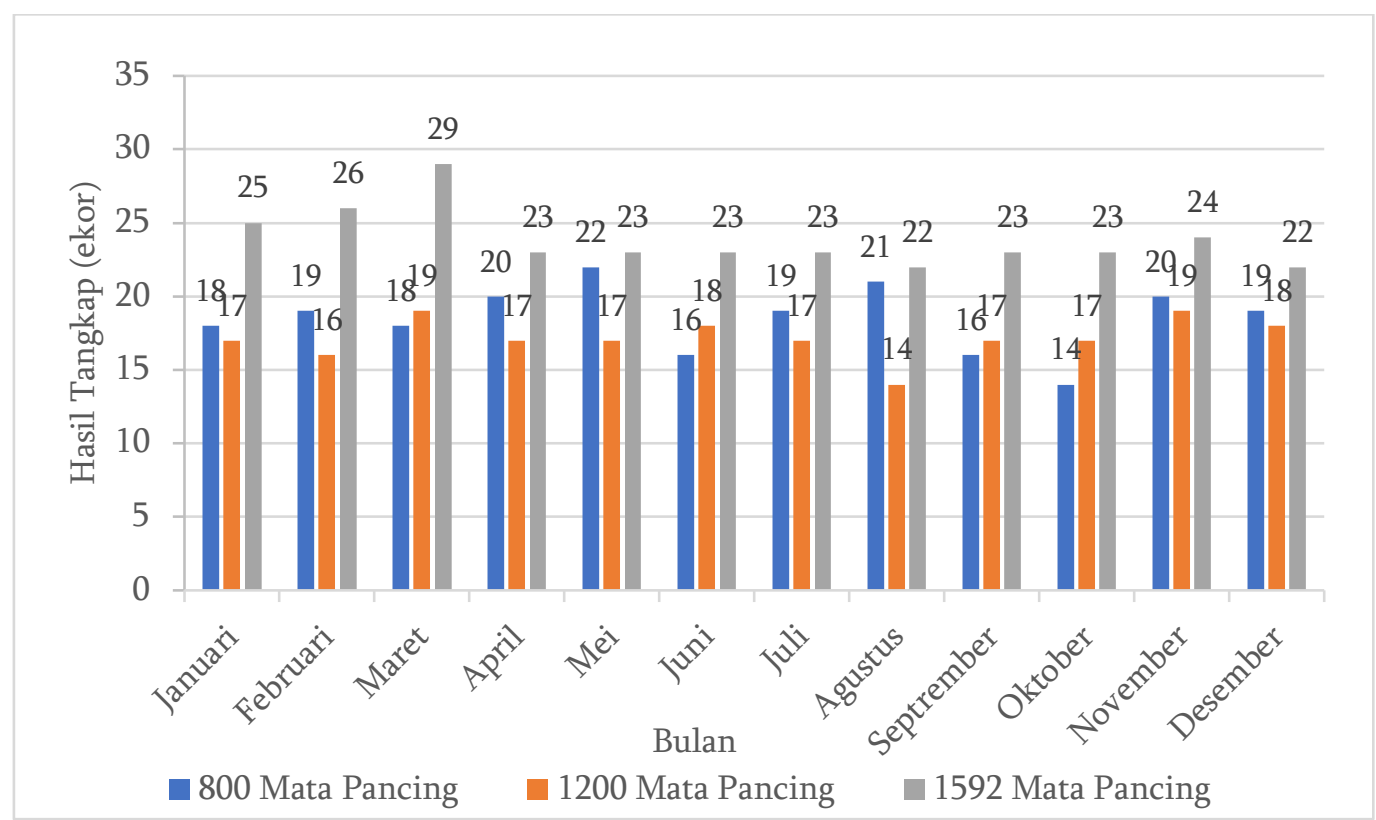

Gambar 2 Jumlah hasil tangkapan ikan tuna sirip kuning tahun 2016 dengan penggunaan jumlah mata pancing berbeda

Pengoperasian alat tangkap longline dengan penggunaan 800 mata pancing memiliki hasil tertinggi pada bulan Mei sebanyak 22 ikan dan jumlah hasil tangkapan terendah pada bulan Oktober sebanyak 14 ikan. Jumlah hasil tangkapan ikan tuna sirip kuning dengan pengoperasian alat tangkap longline dengan penggunaan 1200 mata pancing memiliki hasil tertinggi pada bulan November dan Maret sebanyak 19 ikan dan jumlah hasil tangkapan terendah pada bulan Agustus sebanyak 14 ikan. Jumlah hasil tangkapan ikan tuna sirip kuning dengan pengoperasian alat tangkap longline dengan penggunaan 1592 mata pancing memiliki hasil tertinggi pada bulan Maret sebanyak 29 ikan dan jumlah hasil tangkapan terendah pada bulan Agustus dan Desember sebanyak 22 ikan. Hasil tangkapan ikan tuna sirip kuning pada tahun 2016 dapat diketahui hasil tangkapan dengan jumlah terbanyak yaitu alat tangkap longline yang menggunakan 1592 mata pancing dan hasil tangkapan terendah yaitu alat tangkap longline yang menggunakan 1200 mata pancing. Penggunaan 1592 mata pancing mendapatkan jumlah hasil tangkapan paling banyak dikarenakan beberapa faktor diantaranya sifat renang migrasi dan sifat makan ikan tuna sirip kuning.

Penggunaan alat tangkap dengan 1592 mata pancing memiliki hasil tangkapan terbanyak dikarenakan sifat renang ikan tuna sirip kuning secara bergerombol atau schooling maka apabila penggunaan mata pancing semakin sedikit akan membuat hasil tangkapan semakin menurun dan membuat alat tangkap tersebut menjadi kurang efisien (Gunarso 1998). Penggunaan mata pancing dengan jumlah 800 mata pancing mendapatkan hasil tangkapan cukup baik dibandingkan dengan penggunaan 1200 mata pancing, hal tersebut dapat terjadi karena perbedaan daerah penangkapan dan dipengaruhi oleh jalur migrasi ikan tuna sirip kuning. Sedikitnya jumlah hasil tangkapan yang diperoleh alat tangkap longline dengan 1200 mata pancing juga dipengaruhi oleh banyaknya ikan jenis lain yang tertangkap dan tidak hanya berfokus kepada penangkapan ikan tuna sirip kuning. Hasil tangkapan ikan tuna sirip kuning yang diperoleh alat tangkap dengan 1200 mata pancing tersebut juga dapat diindikasikan bahwa pengoperasian alat tangkap longline yang digunakan sebagian besar digunakan pada kedalaman di bawah lapisan termoklin atau pada kedalaman lebih dari 150 meter di bawah permukaan air laut sehingga ikan tuna sirip kuning yang didapatkan hanya berjumlah sedikit jika dibandingkan dengan kapal penangkap ikan yang menggunakan 800 mata pancing dan 1592 mata pancing. 
Hasil analisis menggunakan Rancangan Acak Kelompok (RAK) terhadap hasil tangkapan dengan tiga perlakuan yaitu perlakuan pertama menggunakan jumlah mata pancing 800 mata pancing, yang kedua menggunakan jumlah mata pancing 1200 mata pancing dan yang ketiga yaitu menggunakan jumlah mata pancing 1592 mata pancing. Pada setiap perlakuan menggunakan dua belas kali ulangan yaitu bulan Januari-Desember (Tabel 1).

Tabel 1 Rata-rata jumlah ikan tuna sirip kuning hasil tangkapan

\begin{tabular}{cc}
\hline Perlakuan & Rata-rata \\
\hline 800 Mata Pancing & $4,29^{\mathrm{ab}}$ \\
1200 Mata Pancing & $4,14^{\mathrm{a}}$ \\
1592 Mata Pancing & $4,88^{\mathrm{c}}$ \\
\hline
\end{tabular}

\section{Bobot Hasil Tangkapan}

Bobot hasil tangkapan ikan tuna sirip kuning yang terbesar dengan pengoperasian alat tangkap longline dengan tali pancing yang menggunakan jumlah mata pancing 800 mata pancing dapat dilihat pada bulan Juli, bobot total hasil tangkapan sebanyak $630 \mathrm{~kg}$ dan bobot total hasil tangkapan terendah terdapat pada bulan Oktober sebanyak $440 \mathrm{~kg}$. Bobot hasil tangkapan ikan tuna sirip kuning terbesar dengan pengoperasian alat tangkap longline dengan tali pancing yang menggunakan jumlah mata pancing 1200 mata pancing dapat dilihat pada bulan November, bobot total hasil tangkapan sebanyak $570 \mathrm{~kg}$ dan bobot total hasil tangkapan terendah terdapat pada bulan Februari sebanyak $450 \mathrm{~kg}$. Bobot hasil tangkapan ikan tuna sirip kuning terbesar dengan pengoperasian alat tangkap longline dengan tali pancing yang menggunakan jumlah mata pancing 1592 mata pancing dapat dilihat pada bulan November, dengan bobot total hasil tangkapan tersebut sebanyak $850 \mathrm{~kg}$ dan bobot total hasil tangkapan terendah terdapat pada bulan Desember sebanyak $730 \mathrm{~kg}$.

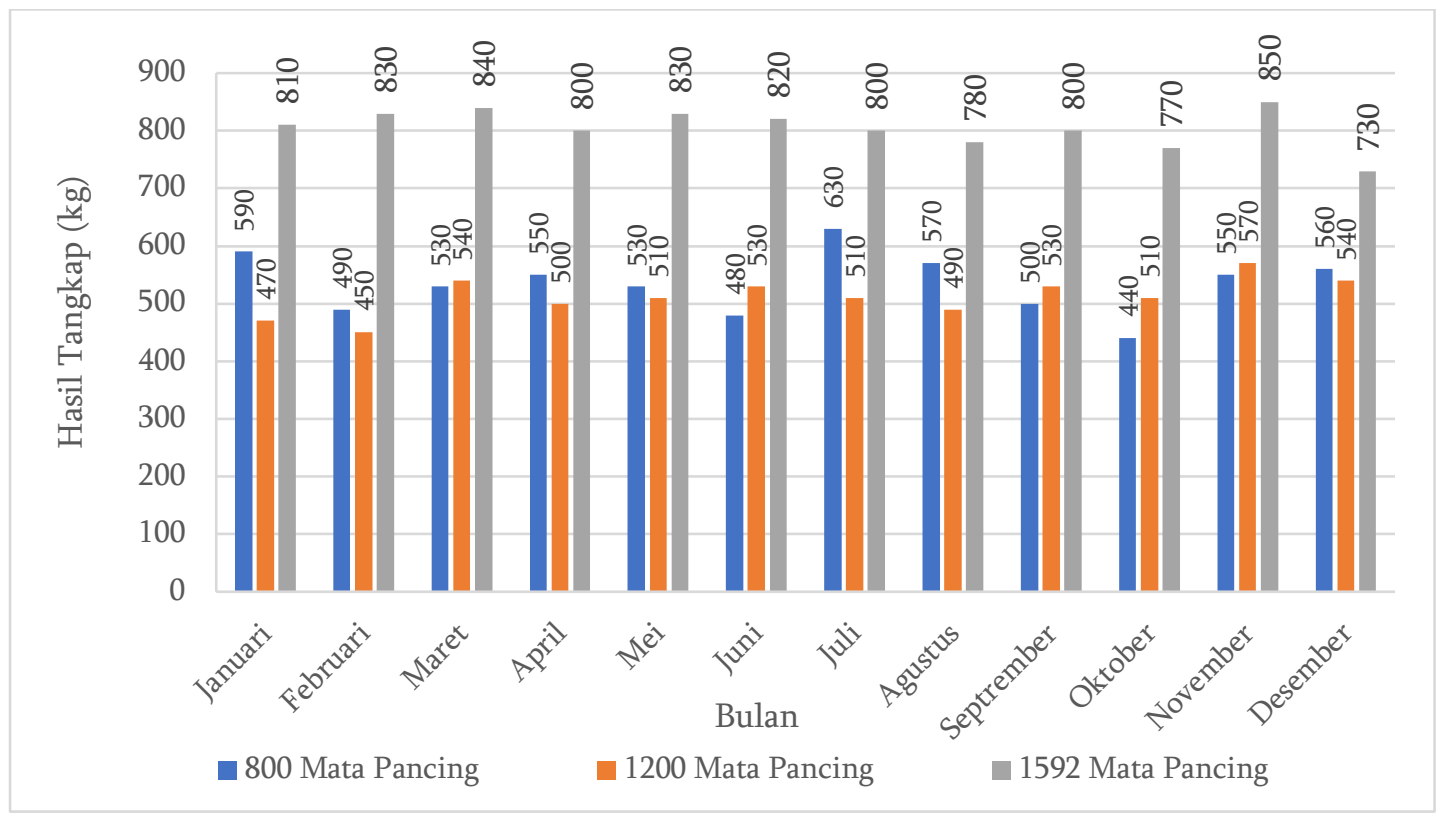

Gambar 3 Bobot hasil tangkapan ikan tuna sirip kuning tahun 2016 pada penggunaan jumlah mata pancing berbeda

Berdasarkan Gambar 3., interaksi antar perlakuan perbedaan jumlah mata pancing menghasilkan jumlah hasil tangkapan yang berbeda nyata, namun untuk setiap ulangan di dalam perlakuan hasilnya tidak signifikan atau tidak terlalu berbeda nyata (Tabel 2). 
Tabel 2 Rata-rata bobot ikan tuna sirip kuning hasil tangkapan

\begin{tabular}{cc}
\hline Perlakuan & Rata-rata \\
\hline 800 Mata Pancing & $2,73^{\mathrm{ab}}$ \\
1200 Mata Pancing & $2,71^{\mathrm{a}}$ \\
1592 Mata Pancing & $2,91^{\mathrm{c}}$ \\
\hline
\end{tabular}

Bobot hasil tangkapan ikan tuna sirip kuning yang tertangkap dengan menggunakan jumlah mata pancing yang berbeda dapat diketahui pola musim penangkapan dan bobot jenis ikan yang bermigrasi pada bulan yang berbeda. Pola musim yang berlangsung di suatu perairan sangat dipengaruhi oleh pola arus yang terjadi karena interaksi antara udara dan laut (Nontji 2007). Interaksi antara udara dan air laut akan mempengaruhi jumlah makanan dan suhu air laut karena akan mempengaruhi hasil tangkapan ikan tuna sirip kuning. Puncak musim ikan tuna sirip kuning di musim peralihan I atau musim pancaroba dimungkinkan karena pada bulan tersebut sedang terjadinya angin musim barat, mengingat terjadinya musim timur atau barat bisa terjadi lebih cepat dan tidak menentu (Purwanto 2013).

\section{Hook Rate}

Nilai hook rate hasil tangkapan ikan tuna sirip kuning dengan pengoperasian alat tangkap longline dengan penggunaan 800 mata pancing memiliki hasil yang tertinggi terjadi pada bulan Mei dengan nilai sebesar 0,34\% dan nilai hook rate hasil tangkapan terendah terjadi pada bulan Oktober sebesar 0,25\%. Nilai hook rate hasil tangkapan ikan tuna sirip kuning dengan pengoperasian alat tangkap longline dengan pengunaan 1200 mata pancing memiliki hasil yang tertinggi terjadi pada bulan Januari, Maret dan November dengan nilai sebesar 0,20 dan nilai hook rate terendah pada bulan Agustus sebesar 0,15\%. Nilai hook rate hasil tangkapan hasil tangkapan ikan tuna sirip kuning dengan pengoperasian alat tangkap longline dengan pengunaan 1592 mata pancing memiliki nilai yang tertinggi terjadi pada bulan Maret sebesar 0,23\% dan nilai hook rate hasil tangkapan ikan tuna sirip kuning terendah terjadi pada bulan Agustus dan Desember dengan nilai sebesar 0,17\% yang ditunjukkan pada Gambar 4.

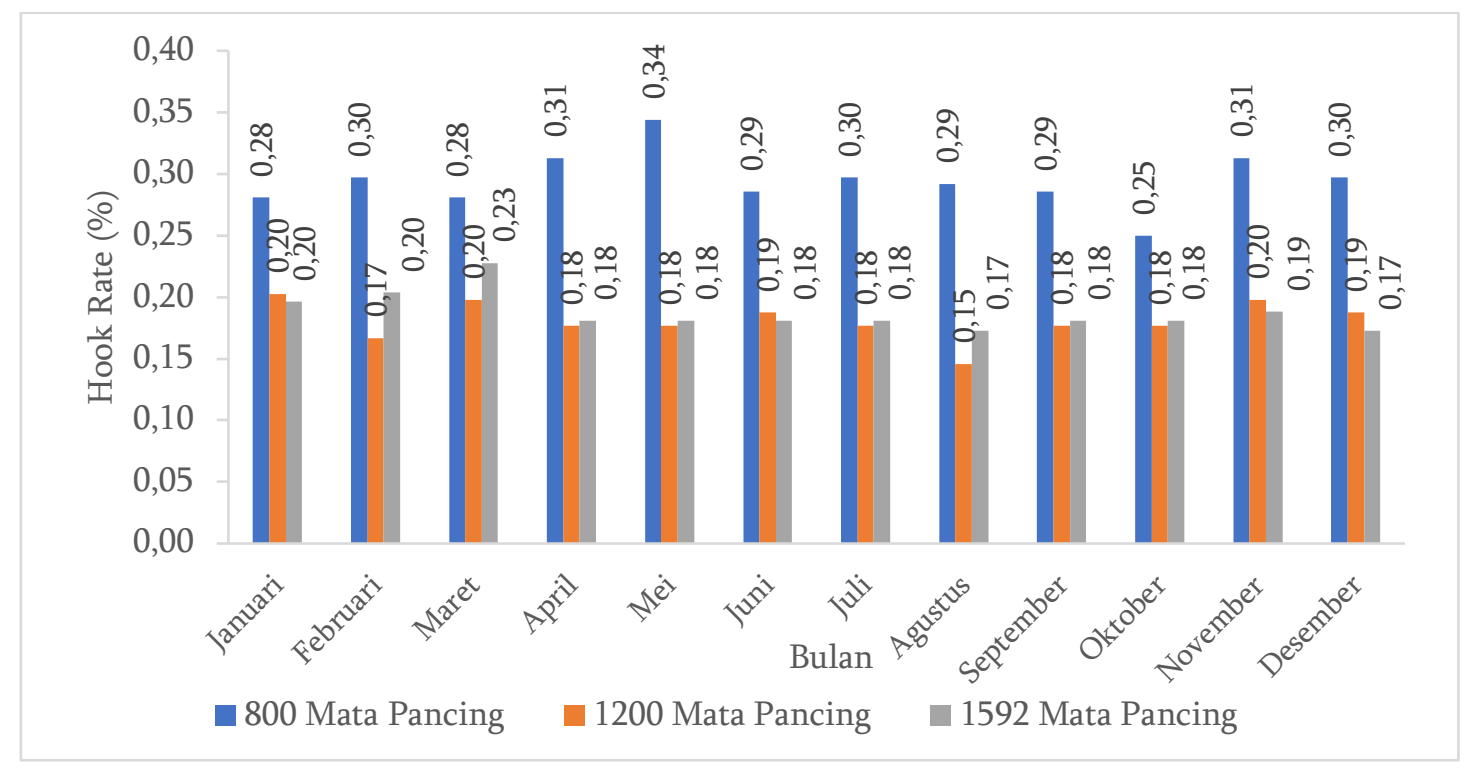

Gambar 4 Hook rate ikan tuna sirip kuning tahun 2016 pada penggunaan jumlah mata pancing yang berbeda 
Penggunaan jumlah mata pancing juga dapat mempengaruhi hasil tangkapan, karena pada tiga kapal yang beroperasi juga memiliki jumlah mata pancing yang berbeda walaupun tidak terlalu berbeda jauh dalam penggunaan mata pancingnya. Perbedaan laju pancing tuna longline dapat disebabkan oleh perbedaan jenis umpan, teknologi alat tangkap longline dan keterampilan anak buah kapal (Bahar 1987). Nilai-nilai hook rate yang diketahui dalam satu musim penangkapan dapat digunakan untuk kapal penangkap ikan sebagai acuan untuk operasi penangkapan selanjutnya agar dapat langsung menuju ke daerah-daerah yang memiliki nilai hook rate cukup tinggi. Oleh karena itu, kapal-kapal tersebut dapat menekan atau mengurangi biaya operasional dalam melakukan operasi penangkapan ikan. Hasil penelitian mengindikasikan penangkapan tuna terbaik dalam satu tahun berlangsung selama dua kali pada awal musim peralihan I (Februari dan Maret) dan pertengahan akhir musim peralihan II (November), hal tersebut sesuai dengan pernyataan Purwanto (2013), dimana puncak musim ikan tuna sirip kuning terjadi pada musim peralihan II atau musim pancaroba akhir.

\section{Analisis Korelasi dan Regresi}

Berdasarkan hasil dalam perhitungan didapat nilai koefisien korelasi sebesar 0,635 yang mana nilai korelasi mendekati nilai 1 , hal tersebut menunjukkan bahwa adanya hubungan antara jumlah hasil tangkapan dan bobot hasil tangkapan atau dapat menunjukkan hubungan yang kuat antara jumlah mata pancing dengan jumlah hasil tangkapan.

Nilai koefisien korelasi menunjukkan melebihi angka 0,5. Angka 0,5-1 merupakan nilai yang menjelaskan bahwa hubungan pengaruh jumlah mata pancing dari tiap perlakuan akan mempengaruhi hasil tangkapan yang memiliki keeratan yang kuat, hal tersebut menunjukkan bahwa adanya pengaruh yang nyata antara perbedaan penggunaan jumlah mata pancing dengan jumlah hasil tangkapan.

Hasil dalam perhitungan didapat nilai regresi sebesar 0,4032 atau 40\% variabel y (jumlah hasil tangkapan) dipengaruhi oleh variabel $\mathrm{x}$ (jumlah mata pancing), sisa dari pengaruh hasil tangkapan bisa dipengaruhi oleh faktor lain misalkan seperti suhu, iklim, pola migrasi ikan, umpan yang digunakan sampai waktu setting dan waktu hauling alat tangkap tersebut (Wudianto, 2003).

Nilai regresi menunjukkan anggka regresi kurang dari 0,5 merupakan nilai yang menjelaskan bahwa adanya hubungan antara penggunaan jumlah mata pancing pada setiap perlakuan dengan hasil tangkapan yang signifikan namun tidak terlalu kuat. Jumlah pancing yang dipasang dalam satu basket atau jumlah mata pancing antar pelampung juga akan mempengaruhi hasil tangkapan, apabila jumlah mata pancing dalam satu basket terlalu banyak maka akan mempengaruhi kedalaman operasi alat tangkap tersebut.

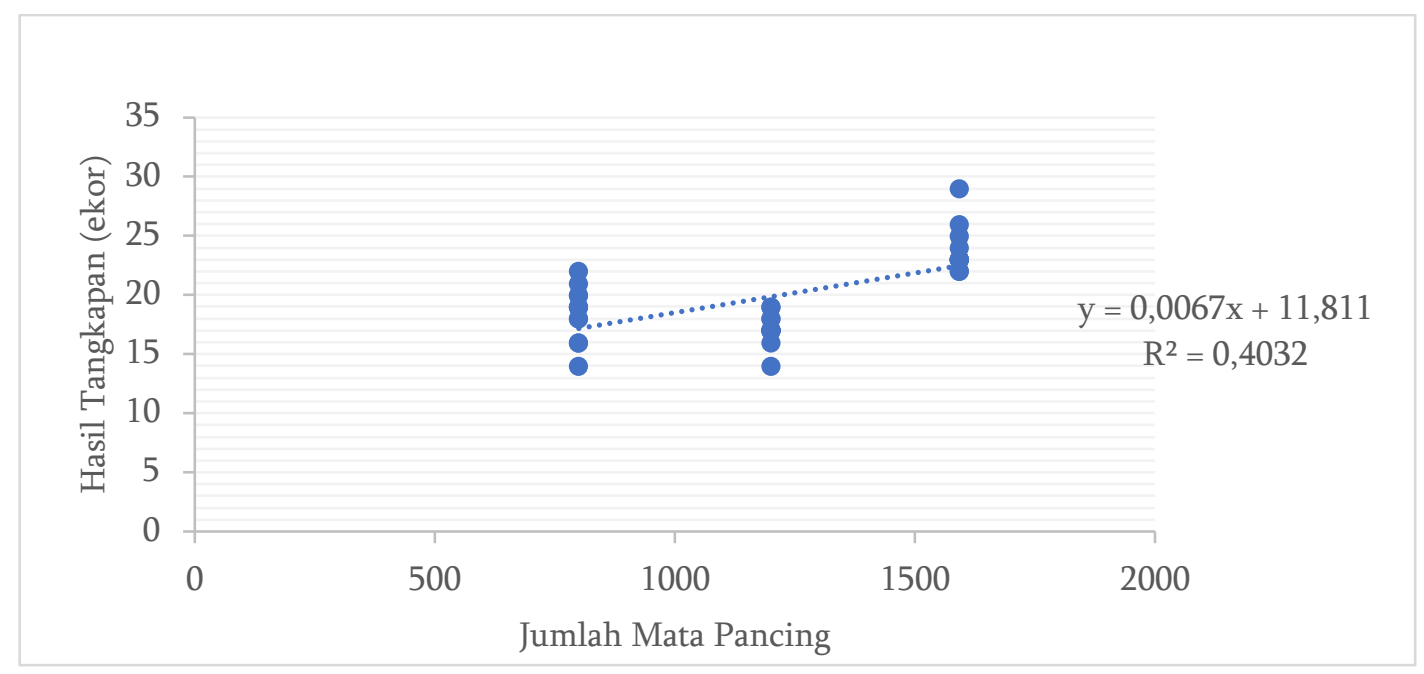

Gambar 5 Analisis regresi bobot hasil tangkapan 
Berdasarkan data operasi penangkapan ikan tuna sirip kuning pada tahun 2016 dengan menggunakan alat tangkap longline yang menggunakan mata pancing dengan jumlah mata pancingnya 800 mata pancing, 1200 mata pancing dan 1592 mata pancing. Dari data tersebut pengoperasian alat tangkap longline yang menggunakan 1592 mata pancing menunjukkan hasil tangkapan tertinggi dan mendominasi pada setiap bulannya di tahun 2016. Dengan demikian dapat disimpulkan bahwa pengoperasian alat tangkap longline paling efektif untuk meningkatkan produksi hasil tangkapan ikan tuna sirip kuning yaitu menggunakan pengoperasian tali pancing dengan 1592 mata pancing.

\section{KESIMPULAN DAN SARAN}

Penggunaan jumlah mata pancing 800, 1200 dan 1592 mata pancing pada alat tangkap longline berpengaruh nyata atau signifikan pada jumlah hasil tangkapan ikan tuna sirip kuning yang tertangkap. Kapal penangkap ikan dengan pengoperasian alat tangkap longline yang menggunakan 1592 mata pancing mendaratkan hasil tangkapan terbanyak dari tiga kapal penangkap ikan yang beroperasi. Jumlah mata pancing yang paling efektif untuk meningkatkan hasil tangkapan yaitu menggunakan 1592 mata pancing.

\section{DAFTAR PUSTAKA}

Ayodhyoa, A U. 1981. Metode Penangkapan Ikan. Bogor (ID): Yayasan Dewi Sri.

Bahar, S. 1987. Studi penggunaan rawai tuna lapisan perairan dalam untuk menangkap tuna mata besar (Thunnus obesus) di perairan barat Sumatera. J. Lit.Perik.Laut. 40:51-63.

Bahtiar A, Barata A, Novianto D. 2013. Sebaran laju pancing rawai tuna di Samudera Hindia. J. Lit.Perik.Ind. 19(4):195-202.

Balai Riset Perikanan Laut. 2003. Hubungan antara suhu dan kedalaman mata pancing terhadap hasil tangkapan bigeye tuna (Thunnus obesus) dan yellowfin tuna (Thunnus albacares) dengan tuna longline di perairan laut banda dan sekitarnya. Laporan Akhir Penelitian. Jakarta (ID): Balai Riset Perikanan Laut.

Barata A, Bahtiar A, Novianto D. 2011. Sebaran ikan tuna berdasarkan suhu dan kedalaman di Samudera Hindia. J.Ilmu.Kel. 16(3):165-170.

Cayré P. 1991. Behaviour of yellowfin tuna (Thunnus albacares) and skipjack tuna (Katsuwonus pelamis) around fish aggregating devices (FADs) in the Comoros Islands as determined by ultrasonic tagging. Aquat.Living.Resour. (4): 1-12.

Dahuri, R. 2008. Restrukturisasi Manajemen Perikanan Tuna. Jakarta (ID): Samudra Komunikasi Utama.

Davis TLO, Farley JH. 2001. Size distribution of southern bluefin tuna (Thunnus maccoyii) by depth on their spawning ground. Fish Bull. 99:381-386.

Direktorat Jenderal Perikanan Tangkap. 2001. Evaluasi Pemanfaatan Sumber Daya Ikan Tuna dan Cakalang di Perairan Samudera Hindia, Laut Sulawesi, dan Samudera Pasifik. Departemen Kelautan dan Perikanan. Jakarta (ID): Direktorat Jenderal Perikanan Tangkap.

Djuhanda T. 1981. Dunia Ikan. Bagian I. Kehidupan Ikan dalam Ekosistem Perairan di Indonesia. Bandung (ID): Armico.,

Gunarso W. 1998. Tingkah Laku Ikan dan Perikanan Pancing. Bogor (ID): Institut Pertanian Bogor.

Klawe WL. 1980. Longlines catches of tunas within the 200 miles Economic zones of the lndian and Western Pacific Ocean. Dev. Rep. Indian Ocean Prog. 48: 83. 
Nakamura H. 1969. Tuna Distribution and Migration. London (UK): Fishing News Book Ltd.

Nugraha B, Triharyuni S. 2009. Pengaruh kedalaman mata pancing rawai tuna (tuna longline) terhadap hasil tangkapan tuna di Samudera Hindia. J.Lit.Perik.Ind. 15(3):239-247.

Martono, Halimurrahman, Komarudin R, Syarief, Priyanto S, Nugraha D. 2008. Studi variabilitas lapisan atas perairan Samudera Hindia berbasis model laut. Surabaya. $7 \mathrm{hlm}$.

Rafiqie M. 2016. Pengaruh jarak tali cabang pada alat tangkap pancing rawai dasar terhadap hasil tangkap ikan dasar di Perairan Selat Madura. [skripsi]. Situbondo (ID): Program Studi Budidaya Perikanan, Akademi Perikanan.

Proctor CH, Sondita FA, Wahju RI, Davis TLO, Gunn JS and Andamari R. 2003. A review of Indonesia's Indian Ocean Tuna Fisheries. ACIAR Project FIS/2001/079.

Pusat Informasi Pelabuhan Perikanan Nizam Zachman Jakarta. 2016.

Sadhori N. 1985. Teknik Penangkapan Ikan. Bandung (ID): Angkasa.

Sadhori S, Naryo. 1995. Budi Daya Rumput Laut. Jakarta (ID): Balai Pustaka.

Subani W dan HR Barus 1989. Alat Penangkapan Ikan di Indonesia. Jakarta (ID): Balai Penelitian Perikanan Laut, Balai Penelitian dan Pengembangan Pertanian, Departemen Pertanian.

Sugiyono. 2013. Metode Penelitian Kuantitatif Kualitatif dan R \& D. Bandung (ID): Alfabeta.

Sumadiharga OK. 2009. Ikan Tuna. Jakarta (ID): Pusat Penelitian Oseanografi. Lembaga Ilmu Pengetahuan Indonesia.

Supadiningsih CN dan Nurul R. 2004. Penentuan Fishing Ground Tuna dan Cakalang dengan Teknologi Penginderaan Jauh. Pertemuan Ilmiah Tahunan I. Teknik Geodesi Institut Teknologi Sepuluh November.

Suryadi A. 1982. Peranan Perikanan Rawai Tuna Dalam Pengelolaan Zona Ekonomi Ekslusif 200 Mil. Bogor (ID): Fakultas Perikanan. Institut Pertanian Bogor. 54 hal.

Syamsuddin ML, Saitoh S, Hirawake T, Bachri S, and Harto AB. 2013. Effects of el niño southern oscillation events on catches of bigeye tuna (Thunnus obesus) in the Eastern Indian Ocean off Java. Fishery Bulletin 111: 175-188.

Widodo J. 1998. Potensi dan Penyebaran Sumberdaya Ikan Laut di Perairan Indonesia. Jakarta (ID): LIPI.

Wijaya H. 2012. Hasil tangkapan madidihang (Thunnus albacares, Bonnaterre 1788) dengan alat tangkap pancing tonda dan pengelolaannya di Pelabuhan Perikanan Nusantara Palabuhanratu, Sukabumi. [tesis]. Bogor (ID): Institut Pertanian Bogor.

Wexler JB, Scholey VP, Olson R, Margulies D, Nakazawa A, \& Suter JM. 2003. Tank culture of yellowfin tuna, Thunnus albacares. developing a spawning population for research purposes. Aquaculture, 220: 327-353. 